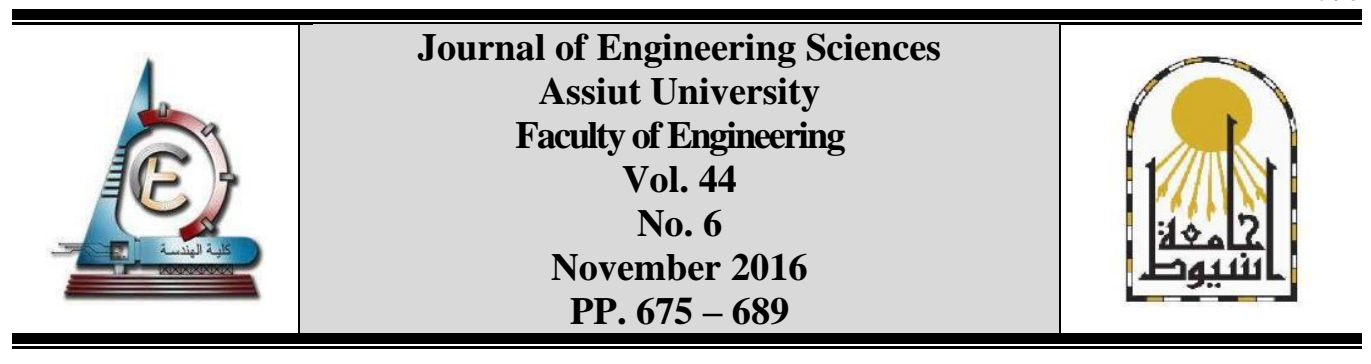

\title{
DEVELOPMENT OF STEEL FIBER-REINFORCED SELF- CONSOLIDATING CONCRETE FOR REPAIRING PURPOSES
}

\author{
Yehia. A. Hassanean, Mohammed M. Ahmed, Kamal Abas Assaf, Amr E. M. Abdallah \\ Civil Engineering Department, Assiut University, Assiut, Egypt.
}

Received 7 August 2016; Accepted 31 September 2016

\section{ABSTRACT}

Fifteen self-consolidating concrete (SCC) as well as five steel fiber-reinforced selfconsolidating concrete (SFR-SCC) mixes using full-length crimped steel fibers were developed and tested in order to optimize a suitable (SFR-SCC) mix for repair of beams. Water-cementitious materials $(\mathrm{w} / \mathrm{cm})$ ratio, sand/coarse aggregate ratio and presence of basalt dust were the main variables taken into consideration. The test results showed that the mix design for the SCC mixes without steel fibers can be achieved by satisfying the flowability criterion. But for the design of selfconsolidating concrete mixes with steel fibers, both the flowability and passing ability criteria must be satisfied. Basalt dust was found to be necessary for SCC mixes without fibers with sand/coarse aggregate ratios of 0.9 and 0.8 , and also for developing SCC mixes with crimped steel fibers. SFRSCC mix with sand/coarse aggregate of 1.1 had satisfactory results in both fresh and hardened properties. SFR-SCC mixes with sand/coarse aggregate of 0.9 and 0.8 did not satisfy fresh properties criteria even with dust/coarse aggregate ratio of 0.4. The suggested SFR-SCC mix was used to repair a beam cracked due to shear stresses. For this purpose, two RC beams were cast and tested under three-point loading. One beam was tested as control beam and the other beam was repaired using the suggested mix. The inclined cracking and ultimate load of the repaired beam were increased by $87.5 \%$ and $91 \%$ comparing to the control beam, respectively. The flexural stiffness was increased significantly for the repaired beam comparing to the control beam. The test results also showed the great contribution of SFR-SCC in both compression and tension zones.
\end{abstract}

Keywords: full-length crimped steel fibers, self-consolidating concrete, steel fiber-reinforced self-consolidating concrete, shear repairing.

\section{Introduction}

The ideal design of self-consolidating concrete (SCC) is the balance between the requirements of flowability and stability to fill the formwork without need for compaction and to avoid segregation during casting or flowing through narrow openings and congested reinforcement, respectively. The flowability of SCC can be achieved using high range water reducing admixtures (HRWRA). The stability of SCC can be obtained by balancing the of aggregate and paste volumes in the mix, choosing cement and cement replacement materials (CRM) or supplementary cementitious materials (SCM) quantities and types, and using viscosity modifying admixtures (VMA) if necessary [9]. Adding steel fibers promotes the mechanical properties of SCC as it does to conventional concrete. However, the addition of fibers compromises the workability of concrete because of its large aspect ratio, large surface 
area and crimped profile. The limit of steel fibers dosage depends on fiber shape and the mixing proportions of SCC. Acceptable workability of SCC requires fibers to be homogenously distributed in the mix without clumping and well-encapsulated by mortar [5].

The aim of this study is to develop steel fiber-reinforced self-consolidating concrete (SFR-SCC) mixes using the locally-available materials and full-length crimped steel fibers. This study investigates the effect of mixing proportions on fresh as well as hardened properties of SCC and SFR-SCC. A suitable SFR-SCC for repairing beams cracked due to shear stresses is developed.

\section{Experimental program}

An intensive experimental program was carried out in order to develop a highly flowable and non-segregating SFR-SCC mix. For this purpose, fifteen non-fibrous SCC mixes were cast and tested to study the effect of the constituent materials on the selfconsolidating behavior. And also to adjust the suitable w/cm ratio for mixing without need for retarding admixtures. Then five SFR-SCC mixes were cast and tested in order to select a suitable mix for the repairing process. A target slump flow ranged between 600 to 650 mm was initially set as well as a target compressive strength of $600 \mathrm{~kg} / \mathrm{cm}^{2}$. The used materials were natural sand, crushed basalt with a maximum size of $9.5 \mathrm{~mm}$, basalt dust (particle size range $0.05-4 \mathrm{~mm}$ ) was used in some mixes as a filler and to increase the paste volume to lubricate the coarse aggregate and steel fibers [3], TYPE I cement with a grade of $32.5 \mathrm{~N}$ was used as it gave the best results among various locally-available types of cement, as determined from preliminary tests on trial mixes as will be discussed later. Also, silica fume was used as a supplementary cementitious material (SCM). The chemical composition of the used cement and silica fume as resulted from tests conducted by CEMEX Egypt as well as their physical properties are listed in Table 1. A modified Polycarboxylates - based HRWRA was used. Also, full - length crimped steel fibers with length of $35 \mathrm{~mm}$, aspect ratio of 50 and tensile strength of $6500 \mathrm{~kg} / \mathrm{cm}^{2}$ were used.

\subsection{Non-fibrous SCC mixes}

Non-fibrous SCC mixes were developed with constant cement content of $500 \mathrm{~kg} / \mathrm{m}^{3}$. Also, silica fume content was fixed at $75 \mathrm{~kg} / \mathrm{m}^{3}$. For each w/cm ratio, a wide range of sand/ coarse aggregate ratios was tested as suggested by many researchers [1, 3, 4]. Sand/ coarse aggregate ratios of $0.8,0.9,1.0,1.1$, and 1.2 were tested. Basalt dust was necessary for mixes with 0.8 and $0.9 \mathrm{sand} /$ coarse aggregate ratios at low w/ $\mathrm{cm}$ ratios in order to provide a sufficient amount of paste to encapsulate the coarse aggregate [3]. HRWRA content was adjusted for each sand/ coarse aggregate and w/cm ratio in order to achieve the desired fresh properties for the mix. Table 2 shows the mixing proportions for non-fibrous SCC mixes. A laboratory pan mixer with maximum capacity of 100 liter was used according to the mixing procedure shown in Fig. 1.a [6]. Slump flow test, T500 test, VSI test, L-box test, V-funnel test and column segregation test were conducted for each mix to evaluate its fresh properties (Fig. 2). Also, $15 \times 15 \times 15 \mathrm{~cm}$ cubes were cast for each mixture to evaluate its compressive strength.

\subsection{SFR-SCC mixes}

To develop SFR-SCC mixes, w/cm ratio was fixed at 0.35 to be used with no need to retarders. It was found that silica fume needed to increase to $90 \mathrm{~kg} / \mathrm{m}^{3}$ in order to achieve the target slump flow with presence of steel fibers. For all mixes, steel fiber volume fraction $(\mathrm{Vf} \%$ ) was fixed at $0.75 \%$ as recommended by some researchers for repairing 
Amr E. M. Abdallah et al., Development of steel fiber-reinforced self-consolidating concrete for ...

Table 1.

Chemical composition and physical properties of the used cement and silica fume

\begin{tabular}{|l|c|c|}
\hline Property & Type I cement & Silica fume \\
\hline $\mathrm{SiO} 2(\%)$ & 21.0 & 86.07 \\
\hline $\mathrm{Al} 2 \mathrm{O} 3(\%)$ & 6.1 & 1.03 \\
\hline $\mathrm{Fe} 2 \mathrm{O} 3(\%)$ & 3.0 & 3.39 \\
\hline $\mathrm{CaO}(\%)$ & 61.5 & 0.55 \\
\hline $\mathrm{MgO}(\%)$ & 3.8 & 2.52 \\
\hline $\mathrm{SO} 3(\%)$ & 2.5 & - \\
\hline $\mathrm{Na}_{2} \mathrm{O}$ & 0.4 & 0.21 \\
\hline $\mathrm{K}_{2} \mathrm{O}$ & 0.3 & 0.99 \\
\hline $\mathrm{Mn}_{2} \mathrm{O}_{3}$ & - & 0.12 \\
\hline $\mathrm{TiO}_{2}$ & - & 0.2 \\
\hline $\mathrm{P}_{2} \mathrm{O}_{5}$ & - & - \\
\hline $\mathrm{Cr} \mathrm{O}_{3}$ & - & 0.02 \\
\hline $\mathrm{CI}(\%)$ & - & - \\
\hline $\mathrm{C}_{3} \mathrm{~A}(\%)$ & - & - \\
\hline Dissolved impurities $(\%)$ & - & - \\
\hline L.O.I. (\%) & 1.4 & 3.50 \\
\hline Specific gravity & 3.15 & 2.0 \\
\hline Initial setting (min) & 90 & - \\
\hline Final setting (min) & 285 & - \\
\hline Fineness (cm $/$ /gm) & 2870 & - \\
\hline
\end{tabular}

Table 2.

Mixing proportions for tested mixes.

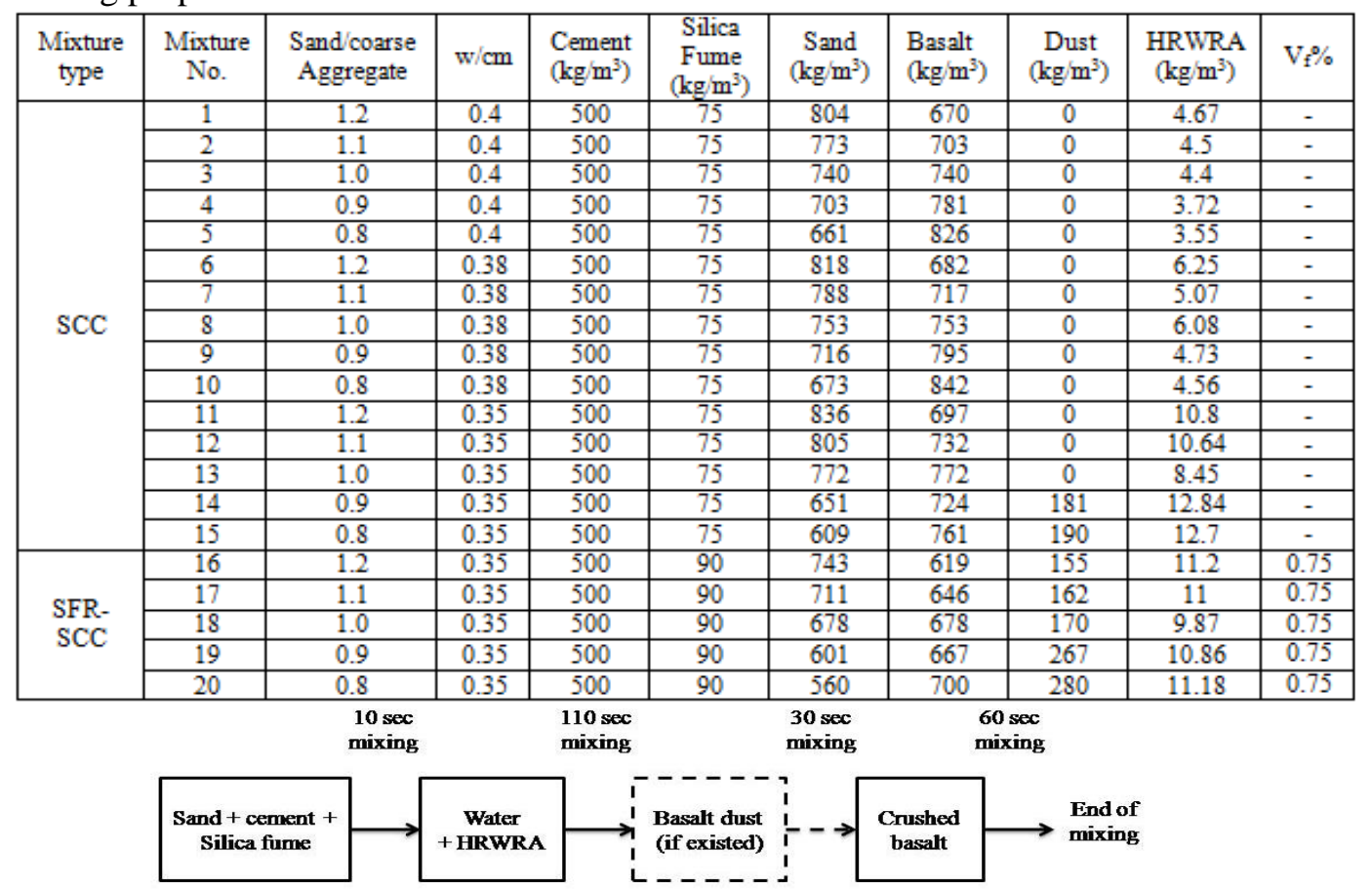

Fig. 1.a. Mixing procedure for non - fibrous SCC mixes. 


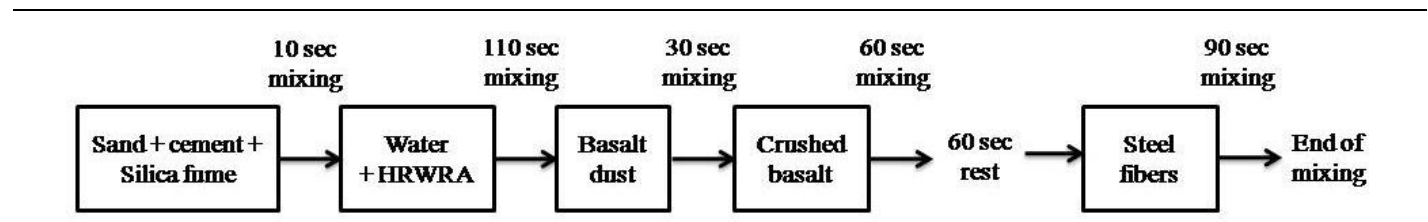

Fig. 1.b. Mixing procedure for SFR-SCC mixes.

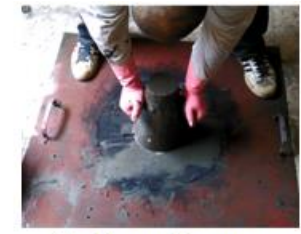

(a) Slump flow test

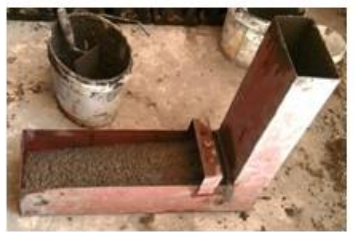

(c) $\mathrm{L}$ - box test

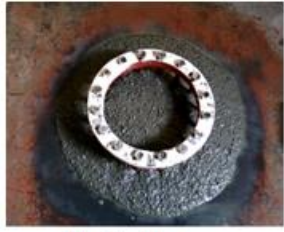

(b) J-ring test

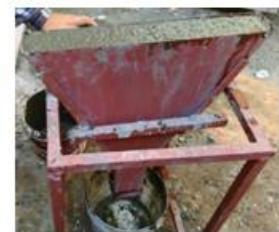

(d) V-funnel test

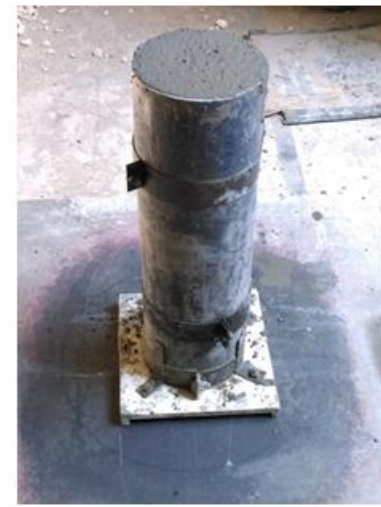

(e) Column segregation test

Fig. 2. Testing mixes for fresh properties.

purposes [4], while dust/ coarse aggregate ratio varied between 0.25 and 0.4 . For each mix, the amount of fibers added was accompanied by a reduction of coarse aggregate only by the same absolute volume [8]. HRWRA content was adjusted for each sand/ coarse aggregate ratio in order to achieve the desired fresh properties for the mix. Table 2 shows the mixing proportions SFR-SCC mixes and Fig. 1.b shows the mixing procedure [6]. Also, slump flow test, T500 test, VSI test, J-ring test, V-funnel test and column segregation test were conducted for each mix to evaluate its fresh properties (Fig. 2). Also, mixes 16, 17, 18, and 19 were developed using other types of cement such as TYPE I cement with a grade of $42.5 \mathrm{~N}$ and TYPE II cement with a grade of $52.5 \mathrm{~N}$. This was done in order to evaluate the efficiency of the various types of cement in terms of fresh and hardened properties. For each mix, $15 \times 15 \times 15 \mathrm{~cm}$ cubes as well as $15 \times 30 \mathrm{~cm}$ cylinders were cast to evaluate its compressive and tensile strength, respectively. The cubes were tested under axial compression while the cylinders were tested under indirect tension. Both tests were conducted using a hydraulic machine with digital display with 150 tons load capacity.

\section{Results and discussion}

The intensive experimental program carried out in this study gave a lot of data to be analyzed and discussed as follows.

\subsection{Non-fibrous SCC mixes}

Initiating the experimental program with developing non-fibrous SCC mixes was to study the self-consolidating behavior of the concrete using the available materials prior to adding steel fibers. The fresh properties as well as compressive strength of SCC mixes are presented in Table 3. The investigation of Figs. 3.a and 3.b shows that sand/coarse aggregate ratio has the same trend effect on both the slump flow and $h_{2} / h_{1}$ ratio except for mixes with sand/coarse aggregate ratio of 0.8 at w/cm of 0.38 and 0.35 . Figs. 3.d, 3.e and 3.c show that v-funnel test results are better correlated with column segregation's than T500's. These correlations can ensure that satisfaction of flowability criteria is sufficient for the mix design 
Amr E. M. Abdallah et al., Development of steel fiber-reinforced self-consolidating concrete for ...

of non-fibrous SCC. Fig. 3.e shows the direct proportion between segregation $\%$ and w/cm ratio. The large drops between segregation percentages of mixes 9 and 14 as well as 10 and 15 are primarily due to the utilization of basalt dust which noticeably enhanced the stability of the mixes. Fig. 4.m shows an earlier version of mix 14 before adding basalt dust. Clear segregation of coarse aggregate can be noticed as the stability of the mix is compromised due to lack of the mortar. Figs. 4 and 5 shows all mixes under slump flow as well as L-box test.

Table 3.

Test results for tested mixes.

\begin{tabular}{|c|c|c|c|c|c|c|c|c|c|c|}
\hline $\begin{array}{l}\text { Mixture } \\
\text { type }\end{array}$ & $\begin{array}{c}\text { Mixture } \\
\text { No. }\end{array}$ & $\begin{array}{l}\text { Slump } \\
\text { flow } \\
(\mathrm{mm}) \\
\end{array}$ & $\begin{array}{c}\mathrm{L}-\mathrm{box} \\
\mathrm{h}_{2} \mathrm{~h}_{1}\end{array}$ & $\begin{array}{c}\text { - ring } \\
\text { flow } \\
(\mathrm{mm}) \\
\end{array}$ & VSI & $\begin{array}{l}\text { T500 } \\
(\mathrm{sec})\end{array}$ & $t_{v}(\mathrm{sec})$ & $\mathrm{S} \%$ & $\begin{array}{c}\mathrm{f}_{\mathrm{cm}} \\
\left(\mathrm{kg} / \mathrm{cm}^{2}\right)\end{array}$ & $\begin{array}{c}\mathrm{f}_{\mathrm{st}} \\
\left(\mathrm{kg} / \mathrm{cm}^{2}\right)\end{array}$ \\
\hline \multirow{15}{*}{$\mathrm{SCC}$} & 1 & 710 & 0.9 & - & 1 & 2.9 & 6.5 & 2.89 & 515.1 & - \\
\hline & 2 & 695 & 0.81 & - & 1 & 2.5 & 6.3 & 3.23 & 547.8 & - \\
\hline & 3 & 610 & 0.8 & - & 1 & 2.3 & 6.0 & 4.46 & 546.2 & - \\
\hline & 4 & 685 & 0.82 & - & 0 & 2.5 & 6.0 & 5.55 & 581.8 & - \\
\hline & 5 & 635 & 0.8 & - & 1 & 2.3 & 5.8 & 6.32 & 575.1 & - \\
\hline & 6 & 650 & 0.8 & - & 0 & 2.3 & 6.8 & 2.15 & 610.9 & - \\
\hline & 7 & 680 & 0.84 & - & 0 & 2.4 & 6.5 & 3.18 & 623.0 & - \\
\hline & 8 & 710 & 0.875 & - & 0 & 2.7 & 6.4 & 3.93 & 585.8 & - \\
\hline & 9 & 660 & 0.84 & - & 1 & 2.3 & 6.3 & 5.33 & 639.0 & - \\
\hline & 10 & 715 & 0.86 & - & 1 & 2.2 & 5.9 & 6.15 & 646.1 & - \\
\hline & 11 & 700 & 0.97 & - & 0 & 2.8 & 7.2 & 1.12 & 632.1 & - \\
\hline & 12 & 680 & 0.93 & - & 0 & 2.9 & 6.9 & 2.66 & 641.1 & - \\
\hline & 13 & 675 & 0.93 & - & 1 & 2.8 & 6.7 & 3.58 & 638.1 & - \\
\hline & 14 & 640 & 0.8 & - & 0 & 3.1 & 6.8 & 2.36 & 640.9 & - \\
\hline & 15 & 725 & 0.91 & - & 1 & 2.6 & 6.5 & 4.68 & 622.9 & - \\
\hline \multirow{5}{*}{$\begin{array}{l}\text { SFR- } \\
\text { SCC }\end{array}$} & 16 & 620 & - & 593 & 0 & 4.6 & 8.9 & 0 & 626.1 & 64.9 \\
\hline & 17 & 640 & - & 603 & 0 & 3.6 & 8.0 & 0 & 652.7 & 69.8 \\
\hline & 18 & 665 & - & 660 & 0 & 3.4 & 8.6 & 4.79 & 612.9 & 57.0 \\
\hline & 19 & 675 & - & 666 & 2 & 3.3 & 8.5 & 13.33 & 660.9 & 65.5 \\
\hline & 20 & 690 & - & 680 & 2 & 2.9 & 7.0 & 17.56 & 606.1 & 58.9 \\
\hline
\end{tabular}

$\mathrm{t}_{\mathrm{v}}=\mathrm{V}$-funnel flow time.

$\mathrm{S} \%=$ percentage of segregation.

$\mathrm{f}_{\mathrm{cu}}=$ cube characteristic compressive strength.

$\mathrm{f}_{\mathrm{ct}}=$ splitting tensile strength.

For all tested mixes, decreasing $\mathrm{w} / \mathrm{cm}$ ratio results in increasing of the compressive strength except for mixes 14 and 15 as shown in Fig. 3.f. This can be explained by the high dosage of HRWRA needed for these mixes to satisfy the fresh properties criteria. Table 4 and Fig. 6 demonstrate the gain of compressive strength for each mix comparing to its version with $\mathrm{w} / \mathrm{cm}$ of 0.4 . For mixes with sand/coarse aggregate ratio of $1.2,1.1$, and 0.9 , the gain in compressive strength is higher between w/cm ratios of 0.4 and 0.38 than the gain between $w / \mathrm{cm}$ ratios of 0.38 and 0.35 . 


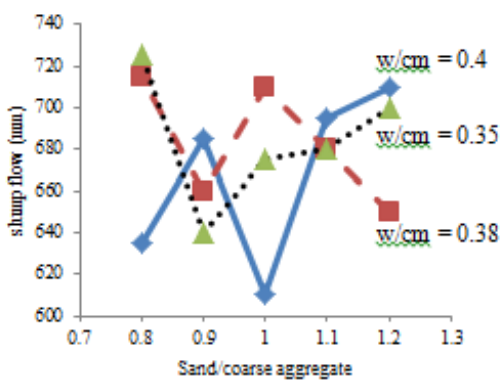

Fig. 3. a. Slump flow - sand/coarse aggregate relationship.

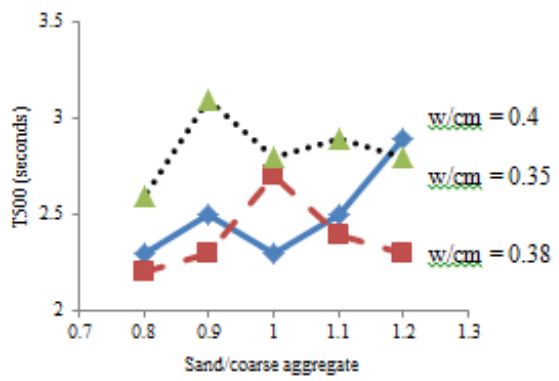

Fig, 3, c. T500 - sand/coarse aggregate relationship.

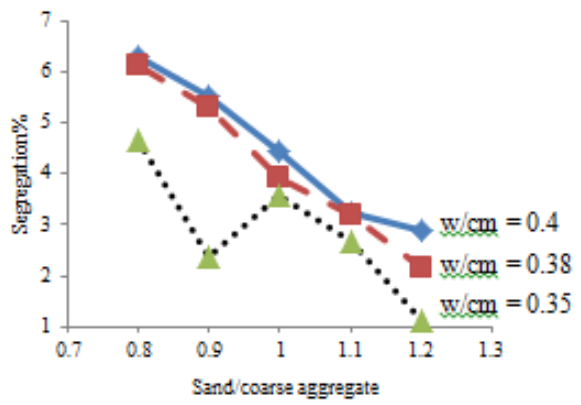

Fig, 3, e. Segregation $\%$ - sand/coarse aggregate relationship.

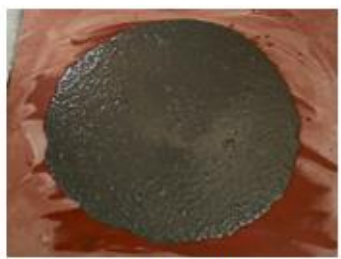

(a) $\operatorname{Mix} 1$

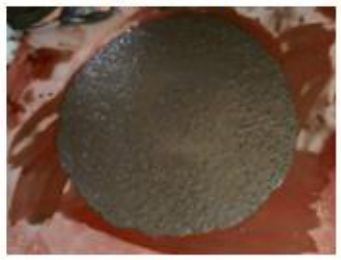

(d) $\operatorname{Mix} 4$

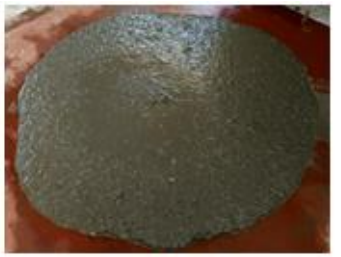

(b) $\operatorname{Mix} 2$

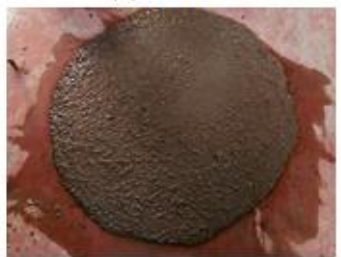

(e) $\operatorname{Mix} 5$

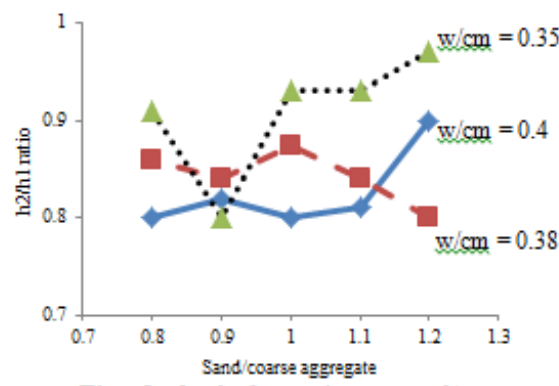

Fig, 3, b. $h_{2} / h_{1}$ ratio - sand/coarse aggregate relationship.

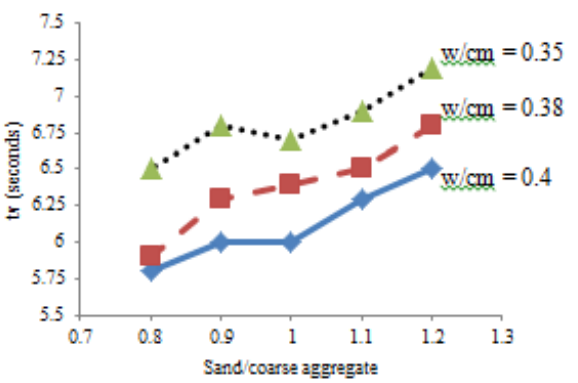

Fig, 3. d. $t_{\mathrm{v}}$ - sand/coarse aggregate relationship.

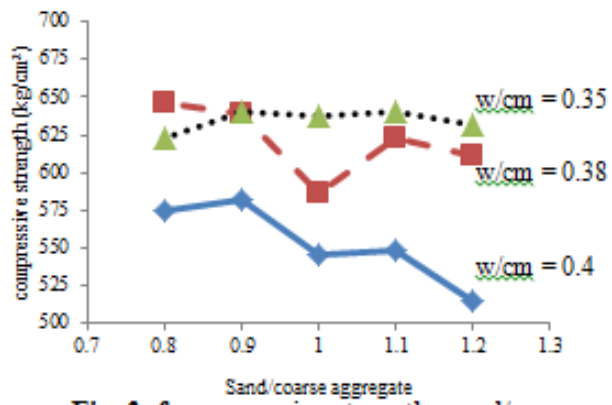

Fig, 3. f. compressive strength-sand coarse aggregate relationship.

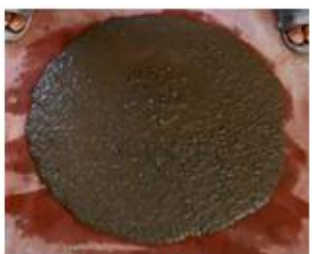

(c) $\operatorname{Mix} 3$

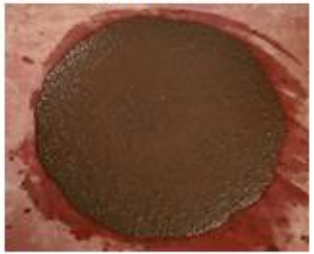

(f) $\operatorname{Mix} 6$ 


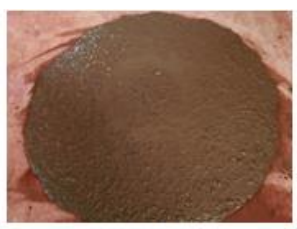

(g) $\operatorname{Mix} 7$

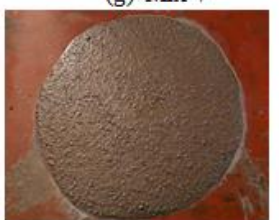

(J) $\operatorname{Mix} 10$

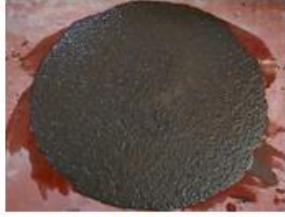

(h) $\operatorname{Mix} 8$

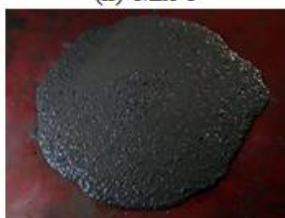

(k) $\operatorname{Mix} 11$

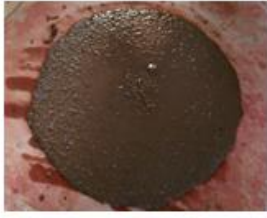

(i) $\quad \operatorname{Mix} 9$

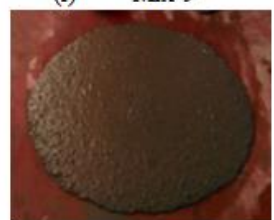

(1) $\operatorname{Mix} 12$

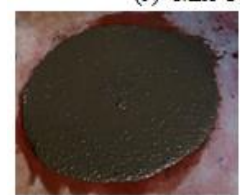

(m) $\mathrm{Mix} 13$

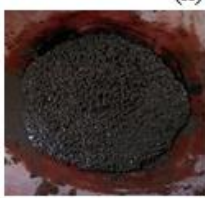

(n) Mix 14

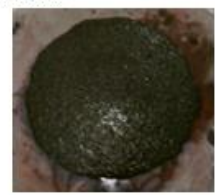

(o) Mix 14

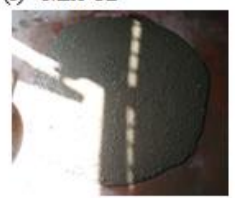

(p) $\operatorname{Mix} 15$

Fig. 4. Slump flow and VSI test results for non-fibrous SCC mixes.

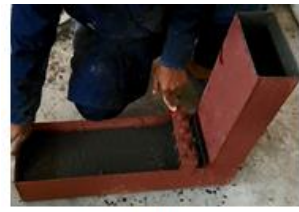

(a) Mix 1

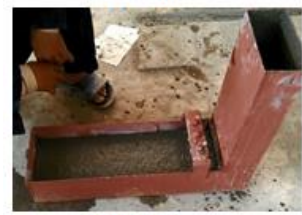

(d) $\operatorname{Mix} 4$

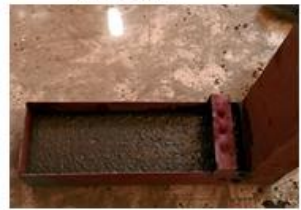

(g) Mix 7

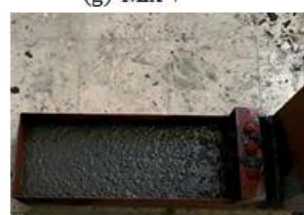

(j) $\operatorname{Mix} 10$

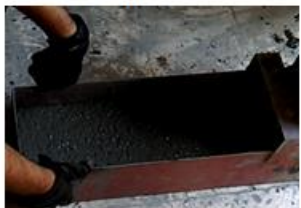

(m) Mix 13

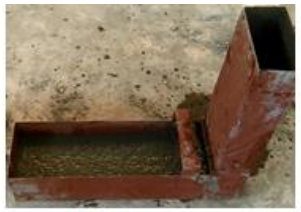

(b) $\operatorname{Mix} 2$

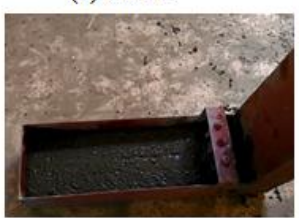

(e) $\operatorname{Mix} 5$

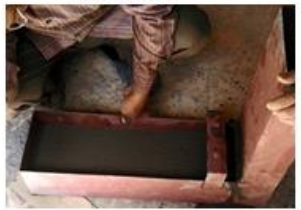

(h) Mix 8

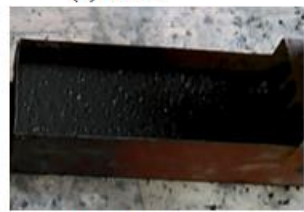

(k) Mix 11

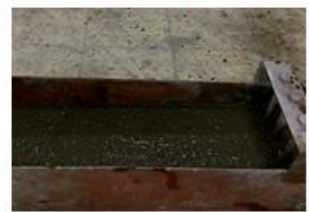

(n) $\operatorname{Mix} 14$

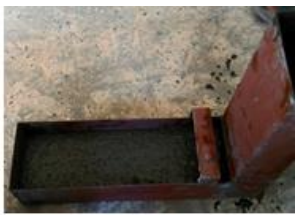

(c) $\operatorname{Mix} 3$

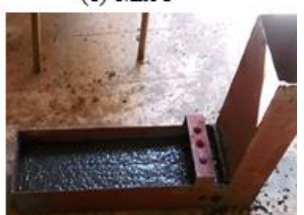

(f) $\operatorname{Mix} 6$

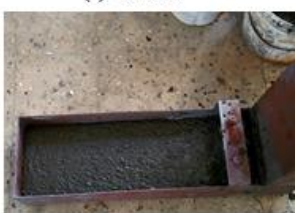

(i) $\operatorname{Mix} 9$

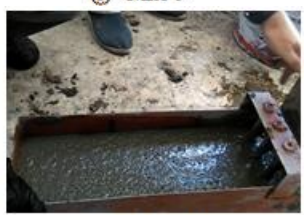

(l) $\mathrm{Mix} 12$

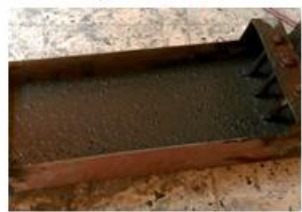

(o) $\mathrm{Mix} 15$

Fig. 5. L-box test results for non-fibrous SCC mixes. 


\section{Table 4.}

percentage gain of compressive strength for non-fibrous SCC mixes.

\begin{tabular}{|c|c|c|c|}
\hline $\begin{array}{c}\text { Mix } \\
\text { No. }\end{array}$ & $\begin{array}{c}\text { \% gain of } \\
\text { compressive } \\
\text { strength }\end{array}$ & $\begin{array}{c}\text { Mix } \\
\text { No. }\end{array}$ & $\begin{array}{c}\text { \% gain of } \\
\text { compressive } \\
\text { strength }\end{array}$ \\
\hline 6 & 18.56 & 11 & 22.71 \\
\hline 7 & 13.73 & 12 & 17.03 \\
\hline 8 & 7.25 & 13 & 16.83 \\
\hline 9 & 9.83 & 14 & 10.15 \\
\hline 10 & 12.35 & 15 & 8.31 \\
\hline
\end{tabular}

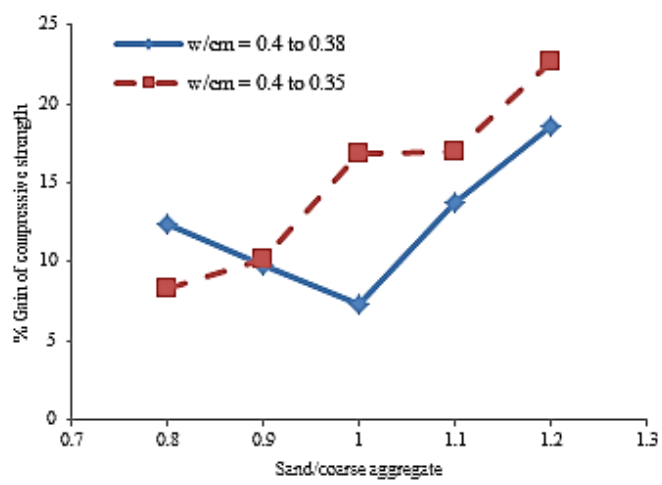

Fig. 6. \%Gain of compressive strength - sand/coarse aggregate relationship.

\subsection{SFR-SCC mixes}

It was necessary to increase the content of silica fume in order to enhance both the flowability and stability of this type of mixes. The crimped profile of the steel fibers significantly compromised the workability in such a way that basalt dust was crucial in order to provide a sufficient mortar volume to encapsulate both the coarse aggregate and the steel fibers. Fig. 7.a shows an earlier version of mix 16 before adding basalt dust. Clear segregation of coarse aggregate and steel fibers can be noticed. Figs. 7.b through 7.f show the mixes after utilization of basalt dust. Table 3 summarizes the test results of SFR-SCC mixes. It should be noted that the results shown in Table 3 are for the mixes developed using TYPE I cement with a grade of $32.5 \mathrm{~N}$. Fig. 8.a shows that increasing sand/coarse aggregate ratio decreases both of slump and J-ring flow. T500 test results are consistent with slump flow's as shown in Figs. 8.a and 8.b. Figs. 8.a, 8.c and 8.d show the integration between flowability, passing ability $(\Delta)$ and stability for the SFRSCC mixes. Mixes 19 and 20 did not satisfy specification limits for segregation resistance as shown in Fig. 8.d, which is also characterized by the nesting of fibers around J-ring bars as shown in Figs.9.d and 9.e. A drop can be noticed in Figs. 8.a and 8.c for mix 17 implying low viscosity comparing to the trend of the curves. However, based on both the fresh and hardened properties, mix 17 is the best as it satisfies fresh properties criteria and has satisfactory compressive and tensile strengths as shown in Figs. 8.e and 8.f. The results of the mixes developed with the other types of cement are presented in Table 5. It's obvious that using TYPE I cement with a grade of $32.5 \mathrm{~N}$ had the best compressive and tensile strength for the different sand/coarse aggregate ratios. Also, the fineness of the TYPE I cement with a grade of $42.5 \mathrm{~N}$ was not constant for all batches. This was evident in the large increase of slump flow for some mixes such as mix 17 and 19 and the decrease of their compression 
and tensile strength compared to the mixes developed with the first type. For the mixes developed with TYPE II cement with a grade of $52.5 \mathrm{~N}$ the compression and tensile strength were either equal to or less than the values for the mixes developed with the first type. Neither grade $42.5 \mathrm{~N}$ cement nor grade $52.5 \mathrm{~N}$ cement changed the fact that mix 19 did not satisfy the specification limits for percentage segregation. That's why mix 20 was not needed to be tested for these types of cement.

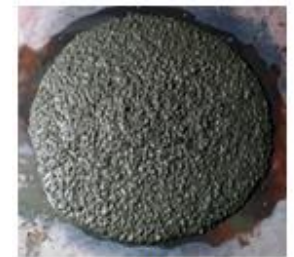

(a) Mix 16

without dust

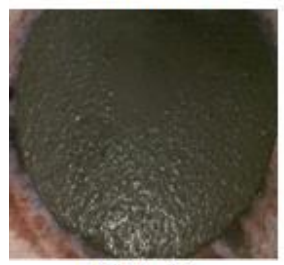

(d) Mix 18

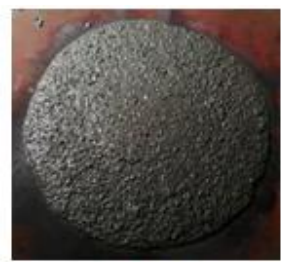

(b) Mix 16

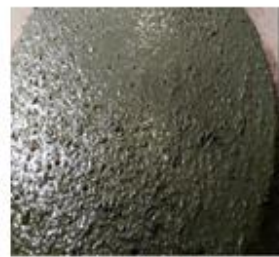

(e) Mix 19

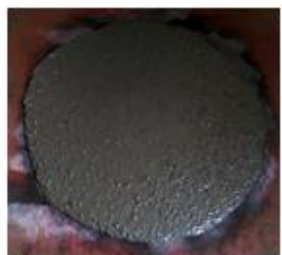

(c) $\operatorname{Mix} 17$

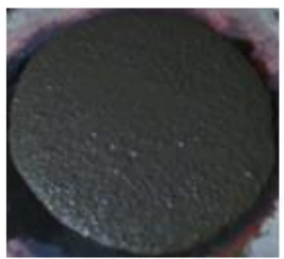

(f) $\operatorname{Mix} 20$

Fig. 7: Slump flow and VSI test results for SFR-SCC mixes.

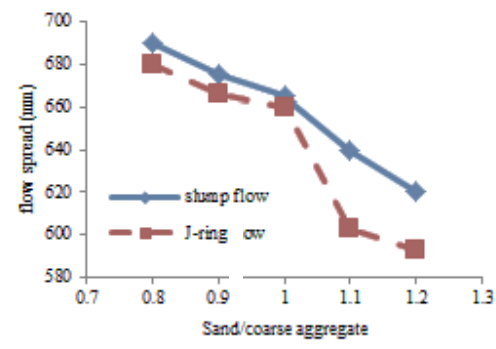

Fig, 8, a. Slump flow \& J-ing flow sand/coarse aggregate relationship.

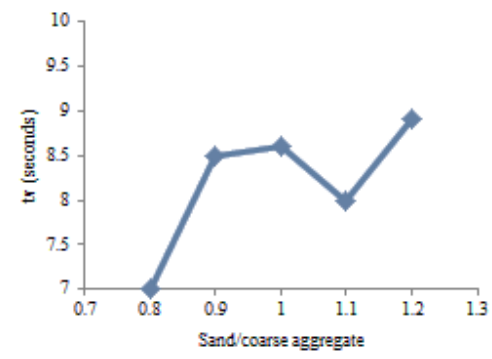

Fig, 8, s. to - sand/coarse aggregate relationship.

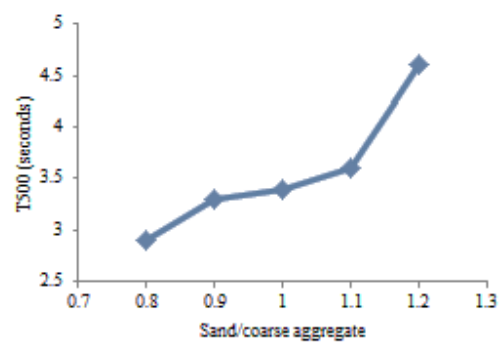

Fig, 8, b. T500 - sand/coarse aggregate relationship.

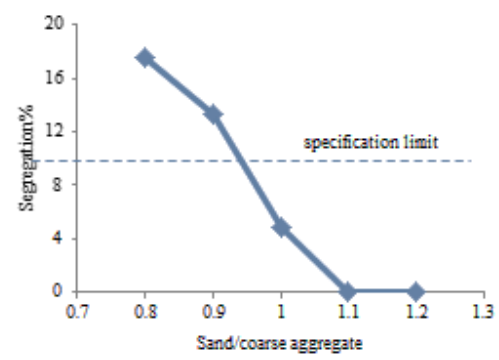

Fig, 8, d. Segregation $\%$ - sand/coarse aggregate relationship. 


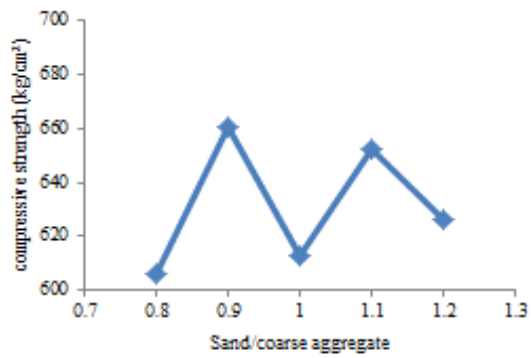

Fig. 8. e. Compressive strength sand/coarse aggregate relationship.

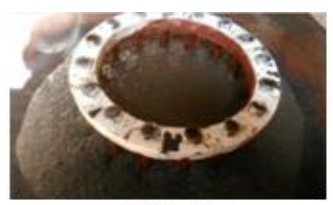

(a) Mix 16

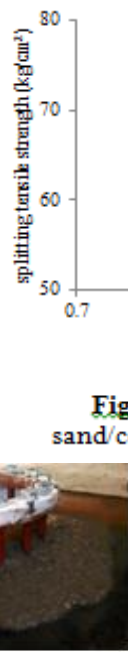

(b) Mix 17
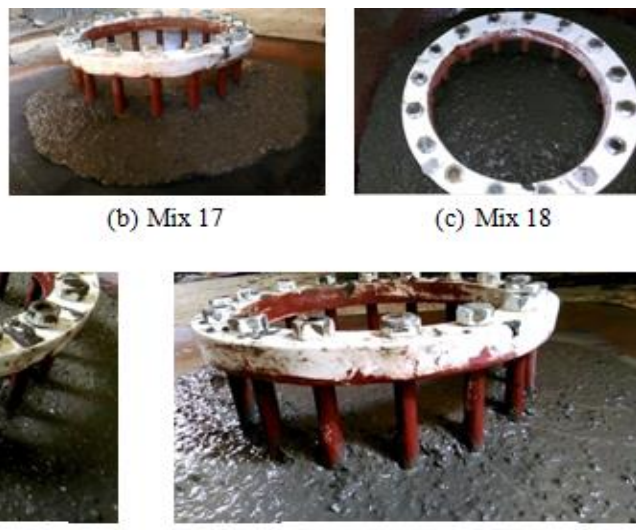

(e) $\operatorname{Mix} 20$

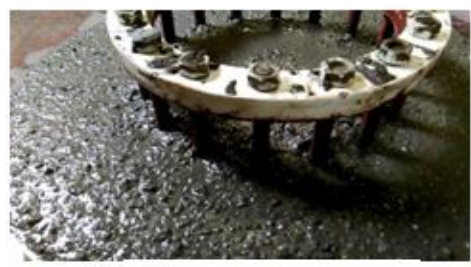

(d) Mix 19
Fig, 8, f. Splitting tensile strength -

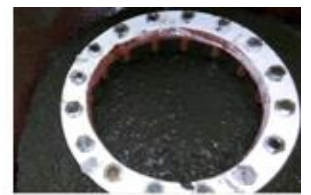

(c) $\operatorname{Mix} 18$

Table 5.

Fig. 9: J-ring flow test results for SFR-SCC mixes.

Test results for tested mixes with different types of cement.

\begin{tabular}{|c|c|c|c|c|c|c|c|c|}
\hline $\begin{array}{l}\text { Mixture } \\
\text { type }\end{array}$ & $\begin{array}{c}\text { Mixture } \\
\text { No. }\end{array}$ & $\begin{array}{l}\text { Slump } \\
\text { flow } \\
(\mathrm{mm})\end{array}$ & $\begin{array}{c}\mathbf{J}-\text { ring } \\
\text { flow } \\
(\mathrm{mm})\end{array}$ & VSI & $\begin{array}{c}\mathrm{t}_{\mathrm{v}} \\
(\mathrm{sec})\end{array}$ & $\mathrm{S} \%$ & $\begin{array}{c}\mathrm{f}_{\mathrm{cu}} \\
\left(\mathrm{kg} / \mathrm{cm}^{2}\right)\end{array}$ & $\begin{array}{c}\mathrm{f}_{\mathrm{ct}} \\
\left(\mathrm{kg} / \mathrm{cm}^{2}\right)\end{array}$ \\
\hline \multirow{15}{*}{$\begin{array}{l}\text { SFR- } \\
\text { SCC }\end{array}$} & \multicolumn{8}{|c|}{ TYPE I cement with a grade of $32.5 \mathrm{~N}$} \\
\hline & 16 & 620 & 593 & 0 & 8.9 & 0 & 626.1 & 64.9 \\
\hline & 17 & 640 & 603 & 0 & 8.0 & 0 & 652.7 & 69.8 \\
\hline & 18 & 665 & 660 & 0 & 8.6 & 4.79 & 612.9 & 57.0 \\
\hline & 19 & 675 & 666 & 2 & 8.5 & 13.33 & 660.9 & 65.5 \\
\hline & \multicolumn{8}{|c|}{ TYPE I cement with a grade of $42.5 \mathrm{~N}$} \\
\hline & 16 & 618 & 569 & 0 & 8.7 & 1.2 & 595.2 & 63.0 \\
\hline & 17 & 700 & 670 & 0 & 7.9 & 0 & 645.1 & 65.7 \\
\hline & 18 & 653 & 604 & 0 & 8.7 & 5.16 & 590.5 & 55.2 \\
\hline & 19 & 720 & 698 & 2 & 7.4 & 16.23 & 643.4 & 65.5 \\
\hline & \multicolumn{8}{|c|}{ TYPE II cement with a grade of $52.5 \mathrm{~N}$} \\
\hline & 16 & 600 & 594 & 0 & 9.0 & 0 & 644.1 & 64.9 \\
\hline & 17 & 623 & 588 & 0 & 7.8 & 0 & 649.2 & 66.9 \\
\hline & 18 & 655 & 618 & 0 & 8.4 & 5.04 & 579.2 & 52.3 \\
\hline & 19 & 683 & 651 & 2 & 8.1 & 14.68 & 639.5 & 60.8 \\
\hline
\end{tabular}

$\mathrm{t}_{\mathrm{v}}=\mathrm{V}$-funnel flow time.

$\mathrm{S} \%=$ percentage of segregation

$\mathrm{f}_{\mathrm{cu}}=$ cube characteristic compressive strength.

$\mathrm{f}_{\mathrm{ct}}=$ splitting tensile strength . 


\section{An application of the produced repairing mixes}

To investigate the efficiency of the suggested SFR-SCC mix for repairing, two reinforced concrete beams (B0) and (B1) designed to fail in shear were cast using normal strength concrete with characteristic strength $200 \mathrm{~kg} / \mathrm{cm}^{2}$. Fig. 10.a shows the details of reinforcement of the tested beams. Beam (B0) had a cross section of $120 \times 300 \mathrm{~mm}$, span $=1620 \mathrm{~mm}$, shear span $=540 \mathrm{~mm}$ with a/d ratio of 2.0. It was reinforced with $2 \Phi 10 \mathrm{~mm}$ as stirrup hanger, $2 \Phi 16 \mathrm{~mm}$ as longitudinal flexural reinforcement and stirrups $\Phi 6 \mathrm{~mm}$ with spacing of 200 $\mathrm{mm}$ as web reinforcement. Beam (B0) had neither shear connectors nor SFR-SCC jacket, and was tested after 28 days under three point loading up to failure as a control beam. The other beam (B1) had a cross section of $120 \times 300 \mathrm{~mm}$, span $=1620 \mathrm{~mm}$, shear span $=540 \mathrm{~mm}$ with a/d ratio of 2.0. It was reinforced with $2 \Phi 10 \mathrm{~mm}$ as stirrup hanger, $2 \Phi 16 \mathrm{~mm}$ as longitudinal flexural reinforcement and stirrups $\Phi 6 \mathrm{~mm}$ with spacing of $200 \mathrm{~mm}$ as web reinforcement. It was loaded up to the first shear cracking. Then both the bottom and sides surfaces were prepared by a grinding disc and drilled to insert shear connectors with $4 \mathrm{~mm}$ diameter as shown in Fig. 10.b with an adhesive mortar. Before casting a U-shaped SFRSCC jacket with $30 \mathrm{~mm}$ thickness using mix 17, a modified epoxy resin-based adhesive was applied to the sides and bottom of the beam. Then the repaired beam (B1) was tested after 28 days under three-point loading up to failure [2]. Tests were conducted using EMS hydraulic machine with 60 tons capacity with the aid of computerized data acquisition system.

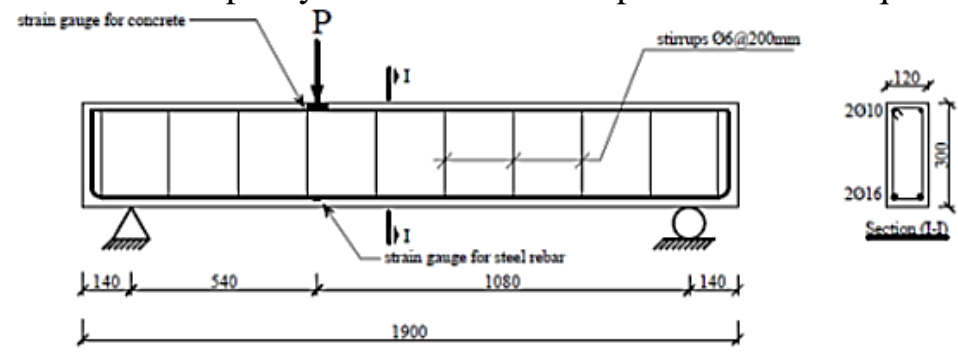

Fig. 10. a. Details of reinforcement for tested beams (Dimensions in mm).
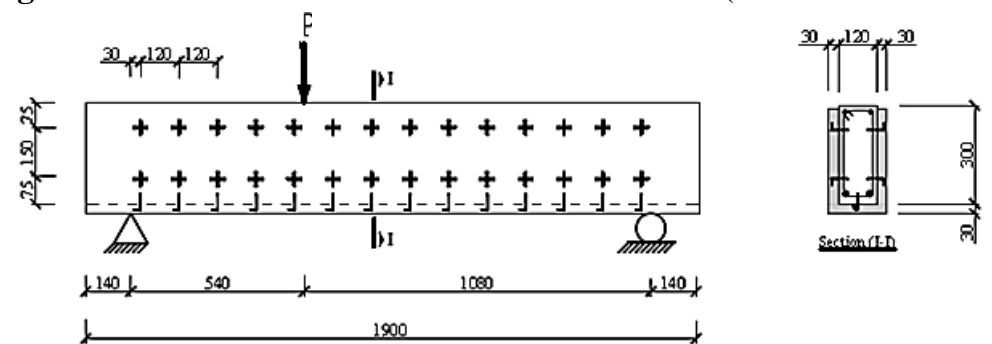

Fig. 10. b. Beam (B1) at repairing process (Dimensions in $\mathrm{mm}$ ).

\section{Results and discussion of the tested beams}

Fig. 11.a and 11.c showed that beam (B0) exhibited a shear-compression failure while beam (B1) exhibited a diagonal-tension failure. The SFR-SCC jacket was found to be beneficial, increasing the cracking load from 4.0 tons for beam (B0) to 7.5 tons for beam (B1), and increasing the ultimate load from 8.85 tons for beam (B0) to 16.9 tons for beam (B1). The jacket also reduced the number of cracks and the mode of failure was more ductile for the repaired beam comparing to beam (B0). 
Fig.12.a. shows that repairing with SFR-SCC significantly enhanced the flexural stiffness for beam (B1) in both pre-cracking and post-cracking stages, comparing to beam (B0). Such increase was found for RC beams when longitudinal steel and/or concrete strength was increased rather than increasing the effective depth of the beam [7]. As presented in neither Fig. 12.b, neither beam (B0) nor (B1) has reached the specified crushing strain of 0.003 by many codes. Beam (B1) exhibited more compressive strain than (B0) at failure. However, for the same load, the repaired beam (B1) exhibited less compressive strain than beam (B0), indicating the contribution of SFR-SCC in the compression zone of the repaired beam (B1). Also, in Fig. 12.c, for the same load the repaired beam (B1) exhibited less steel rebars' tensile strain than beam (B0), indicating the contribution of SFR-SCC in the tension zone of the beam (B1). For the beam (B1) after reaching 10 tons, the tensile strain increased at a lower rate indicating more tensile stresses carried by SFR-SCC at this stage. Table 6 shows cracking loads, ultimate loads, maximum deflections and maximum measured strains for beams (B0) and (B1).

Table 6.

Cracking loads, ultimate loads, maximum deflections and maximum measured strains for tested beams.

\begin{tabular}{|c|c|c|c|c|c|c|c|c|}
\hline Beam & $\begin{array}{c}\mathrm{P}_{\mathrm{cr}} \\
\text { (ton) }\end{array}$ & $\begin{array}{c}\mathrm{P}_{\mathrm{u}} \\
(\text { ton })\end{array}$ & $\begin{array}{c}\mathrm{f}_{\mathrm{cu}} \\
\left(\mathrm{kg} / \mathrm{cm}^{2}\right)\end{array}$ & $\begin{array}{c}\mathrm{f}_{\mathrm{cu}}{ }^{\prime} \\
\left(\mathrm{kg} / \mathrm{cm}^{2}\right)\end{array}$ & $\begin{array}{c}\mathrm{f}_{\mathrm{ct}}{ }^{\prime} \\
\left(\mathrm{kg} / \mathrm{cm}^{2}\right)\end{array}$ & $\begin{array}{c}\delta_{\max } \\
(\mathrm{mm})\end{array}$ & $\begin{array}{c}\varepsilon_{\mathrm{c} \max } \\
(\mu \varepsilon)\end{array}$ & $\begin{array}{c}\varepsilon_{\mathrm{s} \max } \\
(\mu \varepsilon)\end{array}$ \\
\hline BO & 4.0 & 8.85 & 224.8 & - & - & 5.14 & 1076 & 1532 \\
\hline BA1 & 7.5 & 16.9 & 220.7 & 655.8 & 72.1 & 6.64 & 1340 & 1823 \\
\hline
\end{tabular}

\begin{tabular}{|c|c|c|c|c|c|}
\hline Beam & $\begin{array}{c}\mathrm{P}_{\mathrm{cr} \text { B1 }} \\
/ \mathrm{P}_{\mathrm{cr} \text { B0 }}\end{array}$ & $\begin{array}{c}\mathrm{P}_{\mathrm{u} \text { B1 }} \\
/ \mathrm{P}_{\mathrm{u} \text { B0 }}\end{array}$ & $\begin{array}{c}\delta_{\max \mathrm{B} 1} \\
/ \delta_{\max \mathrm{B} 0}\end{array}$ & $\begin{array}{c}\varepsilon_{\mathrm{c} \max \mathrm{B} 1} \\
/ \varepsilon_{\mathrm{c} \max \mathrm{B} 0}\end{array}$ & $\begin{array}{c}\varepsilon_{\mathrm{s} \max \mathrm{B} 1} \\
/ \varepsilon_{\mathrm{s} \max \mathrm{B} 0}\end{array}$ \\
\hline BO & - & - & - & - & - \\
\hline BA1 & 1.875 & 1.91 & 1.29 & 1.25 & 1.19 \\
\hline
\end{tabular}

$\mathrm{P}_{\mathrm{cr}}=$ Inclined cracking load.

$\mathrm{P}_{\mathrm{u}} \quad=$ Ultimate load.

$\mathrm{f}_{\mathrm{cu}}=$ cube characteristic compressive strength of the RC beam.

$\mathrm{f}_{\mathrm{cu}}{ }^{\prime}$ = cube characteristic compressive strength of the SFR-SCC jacket.

$\mathrm{f}_{\mathrm{ct}}{ }^{\prime}=$ splitting tensile strength of the SFR-SCC jacket.

$\delta_{\max }=$ Maximum deflection.

$\varepsilon_{\mathrm{c} \max }=$ Maximum compressive strain for concrete.

$\varepsilon_{\mathrm{s} \max }=$ Maximum tensile strain for steel.
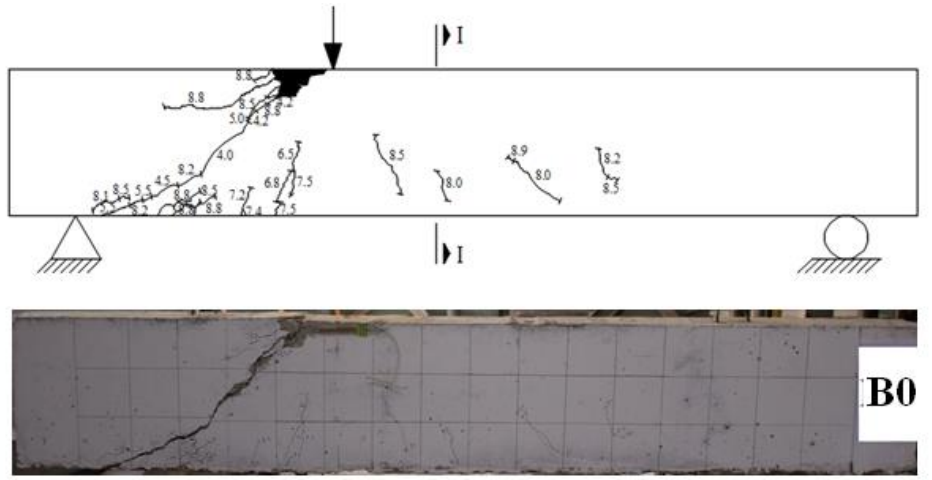

Fig. 11. a. Cracking pattern and mode of failure for beam (B0). 

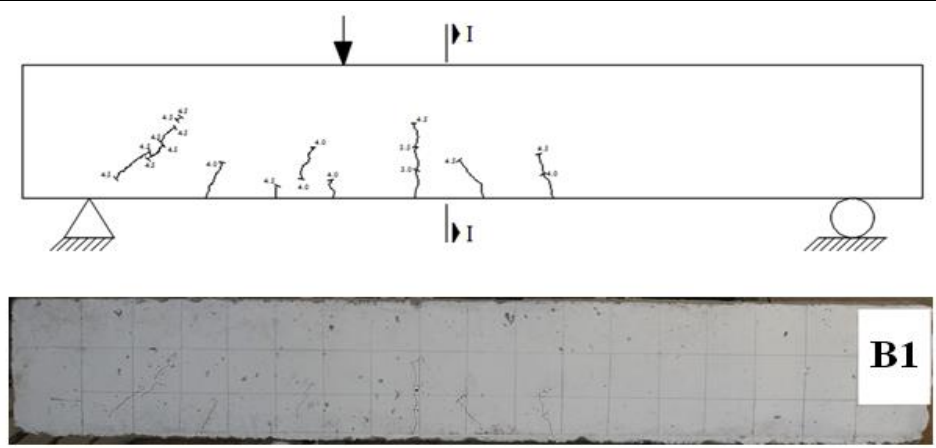

Fig. 11. b. Cracking pattern for beam (B1) before repairing.

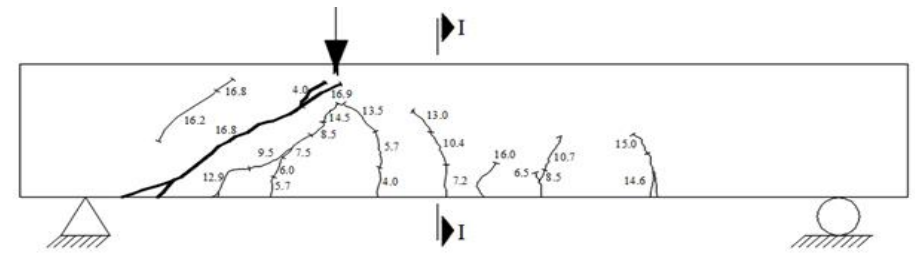

B1

Fig. 11. c. Cracking pattern and mode of failure for beam (B1) after repairing.

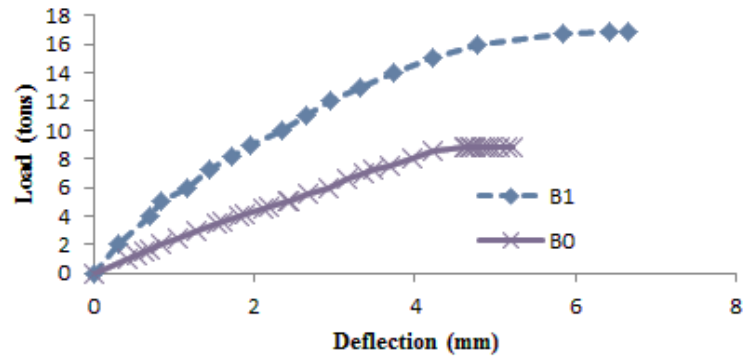

Fig. 12. a. Load-deflection relationships for the tested beams.

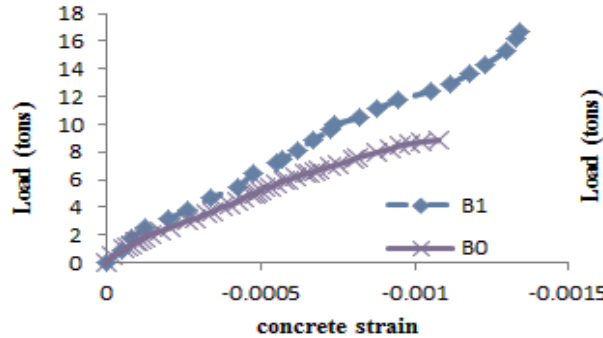

Fig. 12. b. Load- compressive strain relationships for the tested beams.

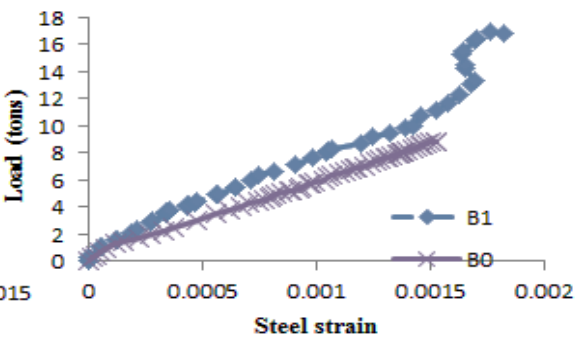

Fig. 12. c. Load- tensile strain relationships for the tested beams.

\section{Conclusions}

Based on the test results and the pre-mentioned discussion, the following conclusions can be drawn:

1- For the non-fibrous SCC mixes, increasing the sand/coarse aggregate ratio can significantly enhance the stability of the mix. However, the compressive strength does not increase in the same manner. 
2- Using of filler such as basalt dust is necessary for the non-fibrous SCC mixes with low sand/coarse aggregate ratio such as 0.9 and 0.8 at w/cm ratio of 0.35 in order to maintain the desired stability of the mix.

3- The addition of crimped steel fibers to self-consolidating concrete mixes can significantly alter their fresh properties.

4- Basalt dust was found to be necessary for SFR-SCC mixes to increase mortar volume to effectively encapsulate both coarse aggregate and the crimped steel fibers. However, it was found that for low sand/coarse aggregate ratio such as 0.9 and 0.8 with $0.75 \%$ volume fraction of crimped steel fibers, the stability criteria could not be achieved. These low sand/coarse aggregate ratios may be used only with low volume fractions of straight steel fibers with crimped ends [3].

5- A suitable mix is obtained with sand/coarse aggregate ratio of 1.1. This mix had a slump flow diameter of $640 \mathrm{~mm}$, a J-ring flow diameter of $603 \mathrm{~mm}$, and zero segregation percentage. It had also compressive and splitting tensile strengths equal 652 and $69.8 \mathrm{~kg} / \mathrm{cm}^{2}$, respectively. These results were found satisfactory for both fresh and hardened properties criteria.

6- The used repairing technique increased the cracking and ultimate loads of the repaired beam comparing to the control beam by $87.5 \%$ and $91 \%$, respectively.

7- The load-deflection relationships showed a significant increase in the flexural stiffness for the repaired beam. The applied repairing technique also changed the mode of failure from shear-compression failure to diagonal-tension failure.

8- At the same load, the repaired beam (B1) exhibited less deflection, compressive and tensile strain than beam (B0). This ensures the great contribution of the SFRSCC jacket in bearing the applied stresses.

\section{REFERENCES}

[1] Alyousif, R (2010). "Design and Testing of Fiber Reinforced Self Compacting Concrete". MSc Thesis, Eastern Mediterranean University, Gazimağusa, North Cyprus.

[2] Arafa, A., (2012). "Strengthening and Repair of R.C Beams Subjected to Short Time Repeated Load by Using Steel Fiber Concrete Jacket". MSc Thesis, Assiut University, Assiut, Egypt.

[3] Deeb, R.. Ghanbari, A., and Karihaloo, B.L. (2012). "Development of self-compacting high and ultra-high performance concretes with and without steel fibers". Cement \& Concrete Composites, 34, 185-190.

[4] Gonzalo Ruano, Facundo Isla, Rodrigo Isas Pedraza, Domingo Sfer, and Bibiana Luccioni (2014). "Shear retrofitting of reinforced concrete beams with steel fiber reinforced concrete". Construction and Building Materials, 54, 646-658.

[5] Grünewald, S., Walraven, J.C. (2003). "Rheological measurements on self-compacting fibre reinforced concrete". In: Wallevik Ó, Níelsson I, editors. Proceedings of the 3rd international RILEM symposium on self-compacting concrete, S.A.R.L France; 2003. p. 49-58.

[6] Grünewald, S., and Walraven, J. C. (2010). "Maximum Fiber Content and Passing Ability of SelfConsolidating Fiber-Reinforced Concrete". ACI Special Publication, 274(2), 15-30.

[7] Mahmoud, K., and El-Salakawy, E. (2016). "Size Effect on Shear Strength of Glass FiberReinforced Polymer-Reinforced Concrete Continuous Beams". ACI Structural Journal, 113(1).

[8] Oliveira, F., (2010). "Design-oriented constitutive model for steel fiber reinforced concrete". $\mathrm{PhD}$ Thesis, Universitat Politècnica de Catalunya, Spain.

[9] Spangenberg J, Roussel N, Hattel JH, Thorborg J, Geiker MR, Stang H, et al. Prediction of the impact of flow-induced in homogeneities in self-compacting concrete (SCC). In: Khayat KH, Feys D, editors. Proceedings of the 2010 international RILEM symposium on self-compacting concrete. Design, production and placement of self-consolidating concreteeds, Canada; 2010. p. 209-14. 
Amr E. M. Abdallah et al., Development of steel fiber-reinforced self-consolidating concrete for ...

\section{تظوير الخرساتة ذاتية الدمك المسلحة بألياف الصلب لأغراض الترميم}

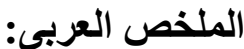

تتعرض بعض العناصر الإنشائية للشروخ نتيجة عدد من العوامل مثل أخطاء التصميم و التنفيذ أو زيادة

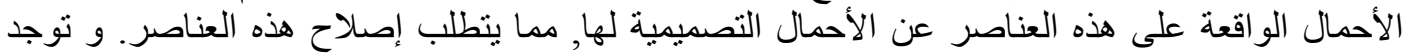

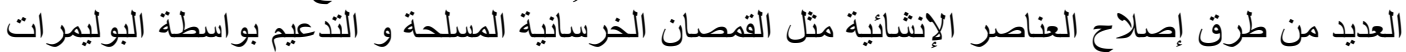

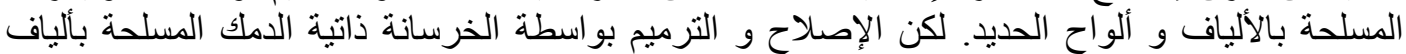

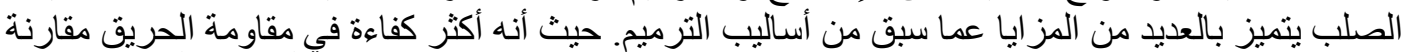

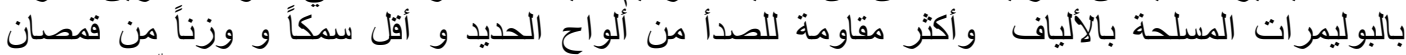

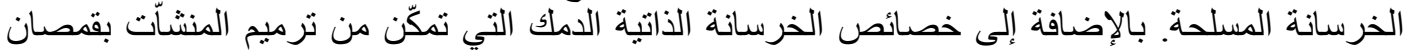
ذات سمك صغير.

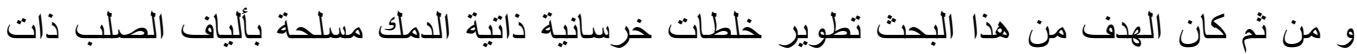

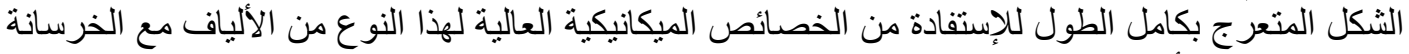

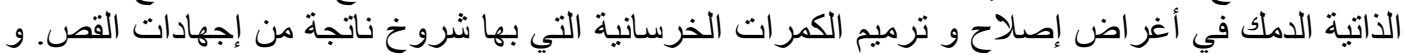

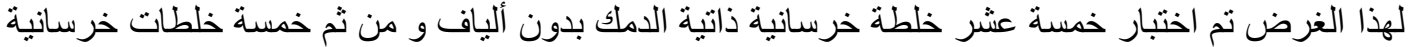

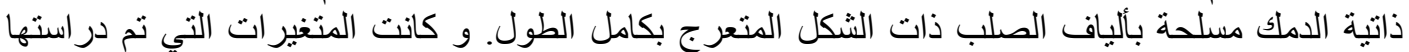

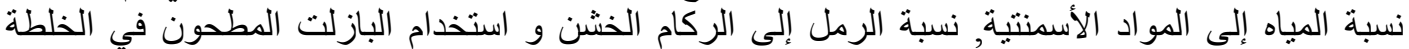

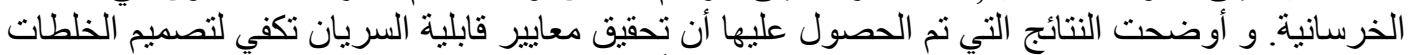

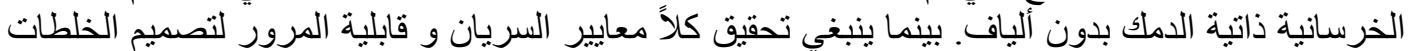

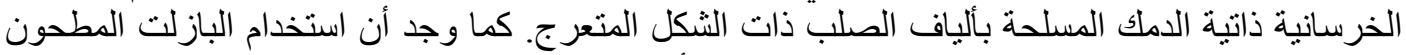

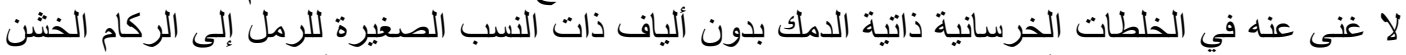

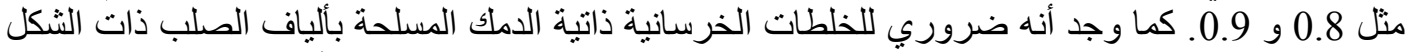

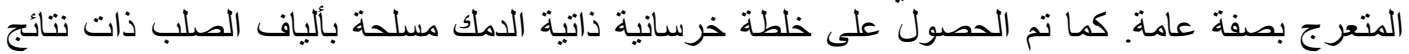

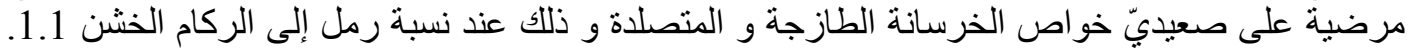
بينما فنلت الخلطات المسلحة بالألياف عند نسبتي الرمل إلى الى الركام الخشن 0.8 و 0.9 في تحقيق حدود المو اصفات لخو اص الخرسانة الطازجة.

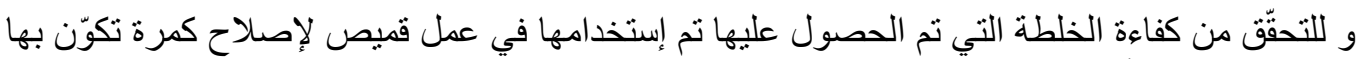

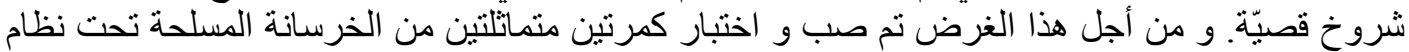
تحميل استاتيكي ثلاثي النقاط. أحد الكمرتين تم اختبار ها ككمرة مرجعية بينما الكمرة الأخرى تم إصلاحتها

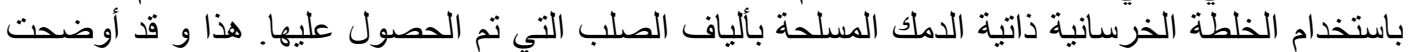

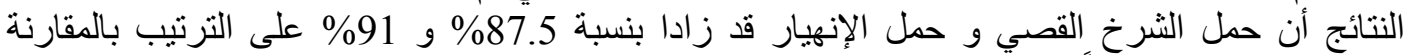

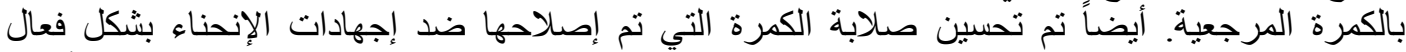

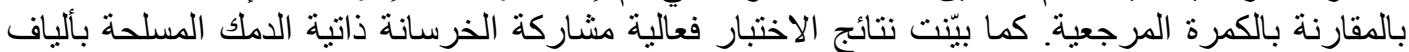

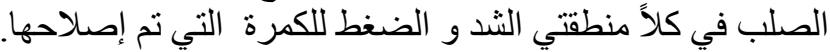

